\title{
ANALISIS KEMAMPUAN PEMAHAMAN DAN PEMECAHAN MASALAH MATEMATIK SISWA SMPN 36 BANDUNG PADA MATERI PERSAMAAN LINEAR SATU VARIABEL
}

\author{
Kameswari Sri Lestari $^{1}$, Siti Nurjanah ${ }^{2}$, Luvy Sylviana Zanthy ${ }^{3}$ \\ 1,2,3 IKIP Siliwangi, J1. Terusan Jenderal Sudirman, Cimahi, Jawa Barat, Indonesia \\ 1kameswarisrilestari14@gmail.com, ${ }^{2}$ sitijanneh@gmail.com, ${ }^{3} 1$ szanthy@gmail.com
}

Diterima: 29 Desember 2018; Disetujui: 22 Mei 2019

\begin{abstract}
This research was conducted with the aim to determine the ability to understand and solve mathematical problem solving skills of students of SMP 36 Bandung in the material of One Variable Linear Equation (PLSV). This research was conducted in the odd semester of the 2018-2019 academic year in Bandung. The population in this study were all students of class VII SMP 36 Bandung with a sample of 30 students namely class VII-E. The instruments used in this research were six comprehension test questions and three math problem solving test questions. This study used qualitative research methods. From the results of the study it can be concluded that errors in the ability to understand and mathematical problem solving abilities of 36 Public Junior High School students in Bandung are relatively low and there is a relationship between understanding ability and mathematical problem solving abilities.
\end{abstract}

Keywords: Understanding Ability, Problem Solving Ability, One Variable Linear Equation

\begin{abstract}
Abstrak
Penelitian ini dilakukan dengan tujuan untuk mengetahui kemampuan pemahaman dan kemampuan pemecahan masalah matematik siswa SMPN 36 Bandung pada materi Persamaan Linear Satu Variabel (PLSV). Penelitian ini dilaksanakan pada semester ganjil tahun ajaran 2018-2019 di Bandung. Populasi dalam penelitian ini adalah seluruh siswa kelas VII SMPN 36 Bandung dengan jumlah sampel 30 siswa yaitu kelas VII-E. Instrumen yang digunakan pada peneitian ini berupa enam soal tes kemampuan pemahaman dan tiga soal tes kemampuan pemecahan masalah matematik. Penelitian ini menggunakan metode penelitian kualitatif. Dari hasil penelitian dapat ditarik kesimpulan bahwa kesalahan dalam kemampuan pemahaman dan kemampuan pemecahan masalah matematik siswa SMPN 36 Bandung tergolong rendah dan terdapat hubungan antara kemampuan pemahaman dan kemampuan pemecahan masalah matematik.
\end{abstract}

Kata Kunci: Kemampuan Pemahaman, Kemampuan Pemecahan Masalah, Persamaan Linear Satu Variabel

How to cite: Lestari, K. S., Nurjanah, S., \& Zanthy, L. S. (2018). Analisis Kemampuan Pemahaman dan Pemecahan Masalah Matematik Siswa SMPN 36 Bandung pada Materi Persamaan Linear Satu Variabel. JPMI- Jurnal Pembelajaran Matematika Inovatif , 2 (3), 107-118.

\section{PENDAHULUAN}

Pendidikan memiliki peranan yang teramat penting bagi pembangunan bangsa dan Negara. Berdasarkan perkembangan ilmu pengetahuan dan teknologi yang mengharuskan seseorang untuk dapat menguasai informasi dan pengetahuan, kemampuan tersebut memerlukan 
pemikiran yang logis, sistematis, kritis, dan kreatif. Oleh karena itu dibutuhkan suatu kemampuan dalam memperoleh, memilih dan mengelola informasi melalui kemampuan berpikir logis, sistematis, kritis dan kreatif. Salah satu mata pelajaran yang dapat meningkatkan kemampuan-kemampuan tersebut adalah matematika (Fadhila \& Sei, 2018).

Merujuk pada pernyataan diatas, maka dapat dinyatakan bahwa kualitas Sumber Daya Manusia (SDM) akan meningkat dengan adanya pembelajaran matematika. Suherman (Muhsin, Johar, \& Nurlaelah, 2013) berpendapat bahwa "(a) Kedudukan Matematika sebagai pusat dari ilmu pengetahuan dalam arti bahwa matematika sebagai ilmu dasar yang wajib dipelajari di setiap tingkatan kelas pada satuan pendidikan baik tingkat dasar, menengah dan tinggi. Karena seperti yang telah kita ketahui bersama, matematika ada di setiap mata pelajaran. Hal tersebut membuktikan bahwa matematika memiliki manfaat dan peranan yang penting tidak hanya untuk ilmu pengetahuan lain melainkan untuk kehidupan sehari-hari seperti dalam melakukan proses transaksi jual beli, menghitung laba dan rugi serta masih banyak lagi manfaat yang lain, oleh karena itu kita harus benar-benar menguasai matematika agar mampu menjalani kehidupan ini dengan sebaik mungkin, (b) Pembelajaran matematika di sekolah bertujuan untuk melatih siswa agar selalu berorientasi pada kebenaran dengan bersikap logis, disiplin, rasional, kritis, objektif, kreatif, cermat dan dapat bekerja sama secara efektif. Tak hanya itu, matematika juga dapat melatih siswa untuk lebih teliti dan tidak ceroboh dalam mengambil suatu keputusan atau tindakan dalam menjawab pertanyaan atau memecahkan suatu permasalahan karena jika siswa tidak teliti dan salah dalam mengambil tindakan akan menyebabkan siswa memperoleh jawaban yang salah dan dengan belajar matematika siswa akan menjadi pribadi yang lebih sabar dalam menghadapi permasalahan di kehidupan ini karena saat mengerjakan soal matematika, siswa akan dihadapkan pada proses penyelesaian yang cukup panjang dan sulit, saat itulah kesabaran siswa akan terlatih".

National Council of Teacher of Mathematics atau NCTM (Fauziah, 2005), mengungkapkan bahwa standar matematika sekolah haruslah meliputi standar isi dan standar proses, standar proses yaitu kemampuan memecahkan masalah, menalar dan membuktikan keterkaitan, representasi dan komunikasi. Dari semua kemampuan tersebut, maka indikator di dalam kemampuan pemecahan masalah yang cukup erat kaitannya dengan karakteristik matematika, karena di dalam indikator kemampuan pemecahan masalah, siswa dituntut untuk menemukan, menuliskan atau menguraikan langkah-langkah dalam mengerjakan soal atau menyelesaikan suatu permasalahan, sehingga siswa tidak langsung begitu saja menuliskan jawaban tanpa mengetahui langkah-langkah untuk mendapatkan jawaban tersebut. Hal inilah yang mampu melatih siswa untuk berpikir kritis, kreatif dan logis.

Kemampuan pemecahan masalah matematik erat kaitannya dengan unsur-unsur pemahaman siswa dalam pembelajaran matematika. Maka, tahapan pertama dalam memecahkan masalah matematika adalah memahami terlebih dahulu masalah yang terdapat dalam soal. Adapun keterkaitan antara kemampuan pemahaman dengan kemampuan pemecahan masalah matematik yaitu jika seseorang mempunyai pemahaman mengenai konsep matematika maka ia mampu mempergunakannya untuk memecahkan masalah tersebut. Dan jika seseorang mampu memecahkan suatu permasalahan, maka ia harus mempunyai pemahaman mengenai konsep matematika yang sebelumnya sudah dipelajari.

Kemampuan pemahaman matematik dan kemampuan pemecahan masalah matematik merupakan dua kemampuan yang telah dinyatakan standar isi mata pelajaran matematika untuk satuan pendidikan. Menurut Nela (Aida, Kusaeri, \& Hamdani, 2017) dijelaskan bahwa tujuan pembelajaran matematika di sekolah yaitu agar siswa memiliki kemampuan sebagai berikut: 
(1) pemahaman mengenai konsep matematika yaitu mampu menerapkan konsep atau algoritma secara akurat, luwes, tepat dan efesien serta dapat menyatakan keterkaitan antar konsep, (2) melakukan manipulasi matematika dalam membuat abstraksi, menggunakan penalaran pada sifat dan pola, menyusun bukti atau menjelaskan gagasan dan pernyataan matematika, (3) memecahkan masalah seperti kemampuan memahami masalah, menyusun model matematika, menyelesaikan dan menguraikan model matematika untuk memperoleh hasil, (4) mengemukakan ide dengan tabel, diagram, simbol atau media lain untuk menggambarkan keadaan atau masalah, (5) bersikap menghargai terhadap manfaat matematika dalam kehidupan seperti memiliki sikap percaya diri dan giat dalam memecahkan masalah serta adanya minat, rasa ingin tahu dan perhatian untuk mempelajari matematika.

Kemampuan pemahaman matematik menurut Polya, Pollatsek (Hendriana \& Soemarmo, 2014) terdiri dari dua bagian yaitu: (1) pemahaman komputasional, dimana siswa mampu menggunakan rumus terkait perhitungan sederhana dan melakukan perhitungan secara algoritmik, (2) pemahaman fungsional, dimana siswa mampu menghubungkan sesuatu dengan hal lainnya dengan tepat serta mengetahui metode yang dikerjakannya. Berdasarkan pernyataan tersebut, maka dapat kita simpulkan bahwa kemampuan pemahaman matematik adalah kemampuan seseorang dalam menyampaikan kembali ilmu yang sudah ia dapat kepada orang lain, baik secara lisan maupun tulisan agar dapat dipahami oleh orang tersebut.

Uraian diatas menunjukkan bahwa kemampuan pemahaman matematik sangat penting untuk siswa miliki dalam pembelajaran di sekolah. Maka, diperlukan minat dan rasa ingin tahu yang tinggi untuk memiliki kemampuan pemahaman matematik tersebut. Dengan minat dan tekad yang kuat untuk memiliki kemampuan pemahaman matematik, maka akan membantu kita dalam proses pembelajaran antara guru dan siswa didalam kelas. Berdasarkan data yang diperoleh di lapangan saat kegiatan PLP (Program Latihan Profesi), rendahnya kemampuan pemahaman matematik ini ditandai oleh beberapa gejala bahwa sebagian siswa SMPN 36 Bandung belum bisa menentukan cara atau langkah yang sesuai dalam menyelesaikan soal, siswa kurang dalam mengaplikasikan konsep yang telah diajarkan ketika menghadapi soal cerita, siswa merasa kesulitan dalam menjawab pertanyaan yang modelnya sedikit berbeda dengan contoh dan siswa kurang paham dalam menentukan hal-hal yang mereka ketahui dari soal cerita. Maka, faktor utama penyebab rendahnya kemampuan pemahaman matematik siswa, yaitu belum tertanamnya minat dan rasa ingin tahu yang tinggi dalam diri siswa untuk memiliki kemampuan pemahaman matematik. Begitu pula dengan kemampuan pemecahan masalah matematik menurut Sudirta dalam (Aida et al., 2017) bahwa faktor utama penyebab rendahnya kemampuan pemecahan masalah matematik siswa, yaitu pembelajaran yang dilaksanakan selama ini belum mampu mengembangkan kemampuan siswa dalam menyampaikan ide atau gagasan matematika dengan tepat, hal tersebut terjadi karena pada saat proses kegiatan belajar mengajar berlangsung guru kurang kreatif menggunakan pendekatan yang lebih menarik, pendekatan yang dapat melatih siswa berpikir kreatif dan kritis untuk diterapkan di dalam kelas sehingga kemampuan siswa tidak terlatih.

iswa dikatakan memiliki kemampuan pemecahan masalah matematik apabila siswa tersebut mampu menyelesaikan soal sesuai dengan langkah-langkah menurut Polya (Hendriana, Rohaeti \& Soemarmo, 2017) yaitu: (1) memahami permasalahan, (2) mengaitkan unsur yang diketahui dan ditanyakan, (3) menyelesaikan model matematika, (4) menginterpretasi hasil terhadap masalah semula. Gejala kurangnya kemampuan pemecahan masalah matematik di SMPN 36 Bandung terlihat dari beberapa siswa yang masih mengalami kesulitan dalam menyelesaikan soal. Hal ini terlihat ketika guru memberikan latihan berupa soal cerita pada materi Persamaan Linear Satu Variabel (PLSV). Siswa merasa kesulitan ketika menjawab soal yang berbeda 
dengan contoh soal yang sebelumnya guru berikan, beberapa siswa hanya mengingat rumus tanpa mengerti proses memperoleh jawaban tersebut, walaupun sudah ada data yang diketahui tetapi tetap saja mereka sulit menyusun strategi atau proses untuk menemukan jawaban. Selain itu, ketika siswa mendapatkan soal cerita dengan data-data yang mengecoh, sebagian besar siswa ikut terkecoh dan menganggap bahwa semua data yang diberikan pada soal harus digunakan untuk menemukan solusi.

Dari uraian diatas, maka rumusan masalah pada penelitian ini adalah bagaimana kemampuan pemahaman matematik dan kemampuan pemecahan masalah matematik siswa SMPN 36 Bandung dalam menyelesaikan masalah Persamaan Linear Satu Variabel (PLSV). Dipilihnya materi Persamaan Linear Satu Variabel (PLSV) dikarenakan pada materi tersebut jika dituangkan dalam bentuk soal cerita, sebagian besar siswa belum bisa menyelesaikannya. Maka, penulis melakukan penelitian dengan judul "Analisis Kemampuan Pemahaman dan Pemecahan Masalah Matematik Siswa SMPN 36 Bandung Pada Materi Persamaan Linear Satu Variabel".

\section{METODE}

Metode yang digunakan dalam penelitian ini yaitu penelitian deskriptif kualitatif, dengan tujuan untuk mendeskripsikan kemampuan pemahaman matematik dan kemampuan pemecahan matematik siswa pada materi Persamaan Linear Satu Variabel (PLSV) tanpa diberikan perlakuan apapun sebelumnya. Penelitian ini dilaksanakan pada semester ganjil, dimana populasi pada penelitian ini adalah seluruh peserta didik kelas VII SMPN 36 Bandung tahun pelajaran 2018/2019 dengan subjek sebanyak 30 orang siswa. Instrumen yang digunakan yaitu berupa instrumen soal tes dan rubrik penilaian. Adapun data yang diperoleh oleh peneliti yaitu melalui kegiatan tes tertulis yang terdiri dari enam soal kemampuan pemahaman matematik dan tiga soal kemampuan pemecahan masalah matematik serta wawancara.

Indikator kemampuan pemahaman matematik berdasarkan Polya (Hendriana \& Soemarmo, 2014). Dalam penlitian ini kemampuan pemahaman matematik akan diukur dengan menggunakan indikator diantaranya yaitu: (a) Pemahaman komputasional: menggunakan rumus dalam perhitungan sederhana dan melakukan perhitungan secara algoritmik, (b) Pemahaman fungsional: menggabungkan satu konsep dengan konsep yang lain dan mengetahui metode yang dikerjakannya.

Indikator kemampuan pemecahan masalah matematik berdasarkan Polya (Hendriana \& Soemarmo, 2014). Dalam penelitian ini kemampuan pemecahan masalah matematik akan diukur dengan menggunakan indikator diantaranya yaitu: (a) Kegiatan memahami masalah, (b) Kegiatan menyusun strategi pemecahan masalah, (c) Kegiatan melaksanakan perhitungan, (d) Kegiatan menguji kembali kebenaran hasil yang diperoleh.

Merujuk pada pernyataan diatas, maka dapat disimpulkan bahwa indikator pemahaman matematik diukur berdasarkan penggunaan rumus dalam perhitungan sederhananya yang dilakukan secara algoritmik dan juga penggabungan satu konsep ke konsep lainnya dan mengetahui strategi yang dikerjakannya. Sedangkan indikator pemecahan masalah matematik diukur berdasarkan kegiatan siswa dalam memahami masalah, kegiatan siswa dalam menyusun strategi pengerjaan pemecahan masalah, kegiatan siswa dalam melaksanakan perhitungan serta kegiatan siswa dalam memeriksa kembali kebenaran hasil yang diperoleh. 
Instrumen penelitian berupa soal-soal yang disusun berdasarkan indikator kemampuan pemahaman matematik sebanyak enam soal dan kemampuan pemecahan masalah matematik sebanyak tiga soal, yaitu soal realistik yang mengambil pokok bahasan Persamaan Linear Satu Variabel. Dalam penyusunan soal tes tertulis peneliti melakukan diskusi dengan dosen pembimbing mengenai soal yang dibuat sendiri dimana soal tersebut telah memenuhi validitas item karena setelah dilakukan analisis terlihat peserta didik mana yang sudah atau belum menguasai materi yang diajarkan guru dan tentunya soal tes tersebut juga sudah sesuai dengan kurikulum (materi dan ujian) dan telah memenuhi kisi-kisi dalam materi pelajaran di sekolah tersebut.

Teknik analisis data yang digunakan yaitu analisis data kualitatif (Aida et al., 2017) meliputi: (1) reduksi data adalah proses pemilihan hal-hal pokok, penyederhanaan, dan memusatkan pada hal-hal penting. Dalam hal ini, peneliti melakukan kegiatan pengumpulan data hasil tes, dokumentasi dan juga mencatat hasil wawancara mengenai penyelesaian soal yang dikerjakan oleh siswa, (2) data yang disajikan berupa informasi dalam bentuk narasi yang diringkas agar mudah dipahami dan merencanakan tindakan penelitian selanjutnya. Dalam hal ini, peneliti menyusun data hasil tes secara singkat dan akurat sehingga menjadi informasi yang dapat dijamin keabsahannya dan memiliki makna yang tepat, 3) penarikan kesimpulan adalah tahap analisis data yang telah disajikan dalam bentuk tabel. Dalam hal ini, peneliti melakukan pemberian kesimpulan melalui tabel untuk mempermudah individu dalam menyimpulkan hasil dari kegiatan penelitian yang telah dilaksanakan.

Untuk mengetahui persentasi kesalahan-kesalahan setiap indikator kemampuan pemahaman matematik dan kemampuan pemecahan masalah matematik dalam soal realistik pokok bahasan Persamaan Linear Satu Variabel (PLSV) digunakan rumus sebagai berikut:

$$
P=\frac{\text { Total } \sum s}{\text { Total } \sum s+\text { Total } \sum b} \times 100 \%
$$

Keterangan

$\mathrm{P}=$ Persentasi kesalahan yang dialami siswa.

$\sum s=$ Jumlah soal yang salah (mengalami kesalahan dalam memahami konsep dan memecahkan masalah matematik) dari total semua soal.

$\sum b=$ Jumlah soal yang benar (tidak mengalami kesalahan dalam memahami konsep dan memecahkan masalah matematik) dari total semua soal.

Untuk mengetahui tinggi rendahnya persentase kemampuan pemahaman dan kemampuan pemecahan masalah matematik siswa maka peneliti menggunakan acuan sebagai berikut:

Tabel 1. Persentase kemampuan siswa

\begin{tabular}{ll}
\hline Persentase (\%) & Kriteria \\
\hline $0 \leq \mathrm{P}<20$ & Sangat rendah \\
\hline $20 \leq \mathrm{P}<40$ & Rendah \\
\hline $40 \leq \mathrm{P}<60$ & Sedang \\
\hline $60 \leq \mathrm{P}<80$ & Tinggi \\
\hline $80 \leq \mathrm{P}<100$ & Sangat tinggi \\
\hline Arikunto (2009) &
\end{tabular}

Ket: $\mathrm{P}$ adalah persentase kesalahan siswa pada kemampuan pemahaman matematik dan kemampuan pemecahan masalah matematik 


\section{HASIL DAN PEMBAHASAN \\ Hasil}

Subjek dalam penelitian ini yaitu siswa kelas VII-E SMPN 36 Bandung yang berjumlah 30 orang. Kemudian peneliti memberikan beberapa soal tes dengan perinciannya yaitu enam soal kemampuan pemahaman matematik dan tiga soal kemampuan pemecahan masalah matematik. Selanjutnya dilakukan wawancara dengan siswa mengenai soal-soal yang telah dikerjakan. Berdasarkan hasil jawaban siswa terkait permasalahan yang telah diselesaikan maka diperoleh data kemudian dianalisis dengan merujuk kepada indikator kemampuan pemahaman matematik dan kemampuan pemecahan masalah matematik. Agar lebih jelas maka dapat dilihat pada Tabel 2.

Tabel 2. Kesalahan setiap indikator dan jumlah kesalahan setiap indikator yang dialami siswa

\begin{tabular}{|c|c|c|c|c|c|c|c|c|c|}
\hline \multirow{2}{*}{\multicolumn{2}{|c|}{$\begin{array}{l}\text { Kemampuan } \\
\text { Jumlah Item }\end{array}$}} & \multirow{2}{*}{\multicolumn{3}{|c|}{$\begin{array}{c}\begin{array}{c}\text { Indikator Dan } \\
\text { Nomor Soal }\end{array} \\
\text { A }\end{array}$}} & \multirow[t]{3}{*}{ Total } & \multirow{2}{*}{\multicolumn{3}{|c|}{$\begin{array}{c}\begin{array}{c}\text { Indikator Dan } \\
\text { Nomor Soal }\end{array} \\
\text { B }\end{array}$}} & \multirow[t]{3}{*}{ Total } \\
\hline & & & & & & & & & \\
\hline & & 1 & 3 & 5 & & 2 & 4 & 6 & \\
\hline \multirow{2}{*}{ Pemahaman } & $\sum \mathrm{B}$ & 25 & 11 & 21 & 57 & 26 & 22 & 7 & 55 \\
\hline & $\sum \mathrm{S}$ & 5 & 19 & 9 & 33 & 4 & 8 & 23 & 35 \\
\hline \multirow{2}{*}{ Kemampuan } & \multirow{2}{*}{\multicolumn{2}{|c|}{ Indikator }} & \multirow{2}{*}{\multicolumn{2}{|c|}{$\begin{array}{c}\text { Jumlah } \\
\text { Item }\end{array}$}} & \multicolumn{3}{|c|}{ Nomor Item Soal } & \multirow{2}{*}{\multicolumn{2}{|c|}{ Total }} \\
\hline & & & & & 1 & 2 & 3 & & \\
\hline \multirow{8}{*}{$\begin{array}{c}\text { Pemecahan } \\
\text { Masalah }\end{array}$} & \multirow{2}{*}{\multicolumn{2}{|c|}{$\mathrm{A}$}} & $\sum \mathrm{B}$ & & 30 & 27 & 22 & & 79 \\
\hline & & & $\sum \mathrm{S}$ & & 0 & 3 & 8 & & 11 \\
\hline & \multirow{2}{*}{\multicolumn{2}{|c|}{$\mathrm{B}$}} & $\sum \mathrm{B}$ & & 28 & 25 & 20 & & 73 \\
\hline & & & $\sum \mathrm{S}$ & & 2 & 5 & 10 & & 17 \\
\hline & \multirow{2}{*}{\multicolumn{2}{|c|}{$\mathrm{C}$}} & $\sum \mathrm{B}$ & & 25 & 22 & 19 & & 66 \\
\hline & & & $\sum \mathrm{S}$ & & 5 & 8 & 11 & & 24 \\
\hline & \multirow{2}{*}{\multicolumn{2}{|c|}{$\mathrm{D}$}} & $\sum \mathrm{B}$ & & 25 & 20 & 17 & & 62 \\
\hline & & & $\sum \mathrm{S}$ & & 5 & 10 & 13 & & 28 \\
\hline
\end{tabular}

Berdasarkan Tabel 2 maka diperoleh persentase kesalahan tiap aspek indikator kemampuan pemahaman matematik adalah : Indikator A yaitu perhitungan sederhana memiliki kesalahan sebesar 36,67\% maka termasuk dalam kriteria rendah, sedangkan pada indikator B yaitu mengetahui metode yang dikerjakannya memiliki kesalahan sebesar 38,89\% maka termasuk dalam kriteria rendah. Kesalahan-kesalahan siswa pada indikator A yaitu terdapat beberapa siswa yang kurang tepat dalam menerapkan rumus dan kurang dalam melakukan perhitungan secara algoritmik sedangkan kesalahan siswa pada indikator B yaitu terdapat siswa yang belum mampu menggabungkan satu konsep dengan konsep yang lain.

Sedangkan untuk persentase kesalahan tiap aspek indikator kemampuan pemecahan masalah matematik adalah: Indikator A yaitu memahami masalah memiliki kesalahan sebesar 12,22\% maka termasuk dalam kriteria sangat rendah, pada indikator B yaitu menyusun rencana penyelesaian memiliki kesalahan sebesar 18,89\% maka termasuk dalam kriteria sangat rendah, pada indikator $\mathrm{C}$ memiliki kesalahan dalam melaksanakan rencana penyelesaian yaitu sebesar $26,67 \%$ maka termasuk dalam kriteria rendah, dan pada indikator D memiliki kesalahan dalam 
menguji kembali kebenaran jawaban yang sudah diperoleh yaitu sebesar 31,11\% maka termasuk dalam kriteria rendah.

Kesalahan siswa pada indikator A yaitu beberapa siswa hanya menyatakan salah satu dari apa yang diketahui, ditanyakan dan kecukupan data dari soal yang diberikan bahkan terdapat siswa yang tidak menyatakan hal-hal tersebut. Kesalahan siswa pada indikator B yaitu beberapa siswa kurang tepat dalam menyusun rencana penyelesaian dan menuju pada jawaban yang salah. Kesalahan siswa pada indikator $\mathrm{C}$ yaitu beberapa siswa dapat menuliskan penyelesaian masalah berdasarkan rencana akan tetapi jawaban salah, sedangkan pada indikator D kesalahan siswa yaitu beberapa siswa tidak menguji kembali kebenaran jawaban yang sudah diperoleh akan tetapi memberikan kesimpulan dengan tepat dan beberapa siswa pun tidak menuliskan tahapan ini.

Berdasarkan hasil dari analisis kemampuan pemahaman matematik dan kemampuan pemecahan masalah matematik, didapat bahwa ada empat indikator dengan persentase kesalahan rendah dikarenakan masih terdapat siswa yang kurang memahami dan tidak dapat menyelesaikan soal persamaan linear satu variabel yang berbentuk soal uraian, namun begitu masih banyak diantaranya siswa yang cukup mampu memahami soal, menyatakan apa yang diketahui, ditanyakan serta kecukupan data dan menyelesaikan permasalahan dengan benar.

\section{Pembahasan}

Berdasarkan hasil diatas, maka diperoleh siswa dengan skor tertinggi, sedang dan rendah dengan perincian sebagai berikut :

\section{Deskripsi Subjek Berkemampuan Matematika Tinggi dalam Kemampuan Pemahaman dan Kemampuan Pemecahan Masalah Matematik}
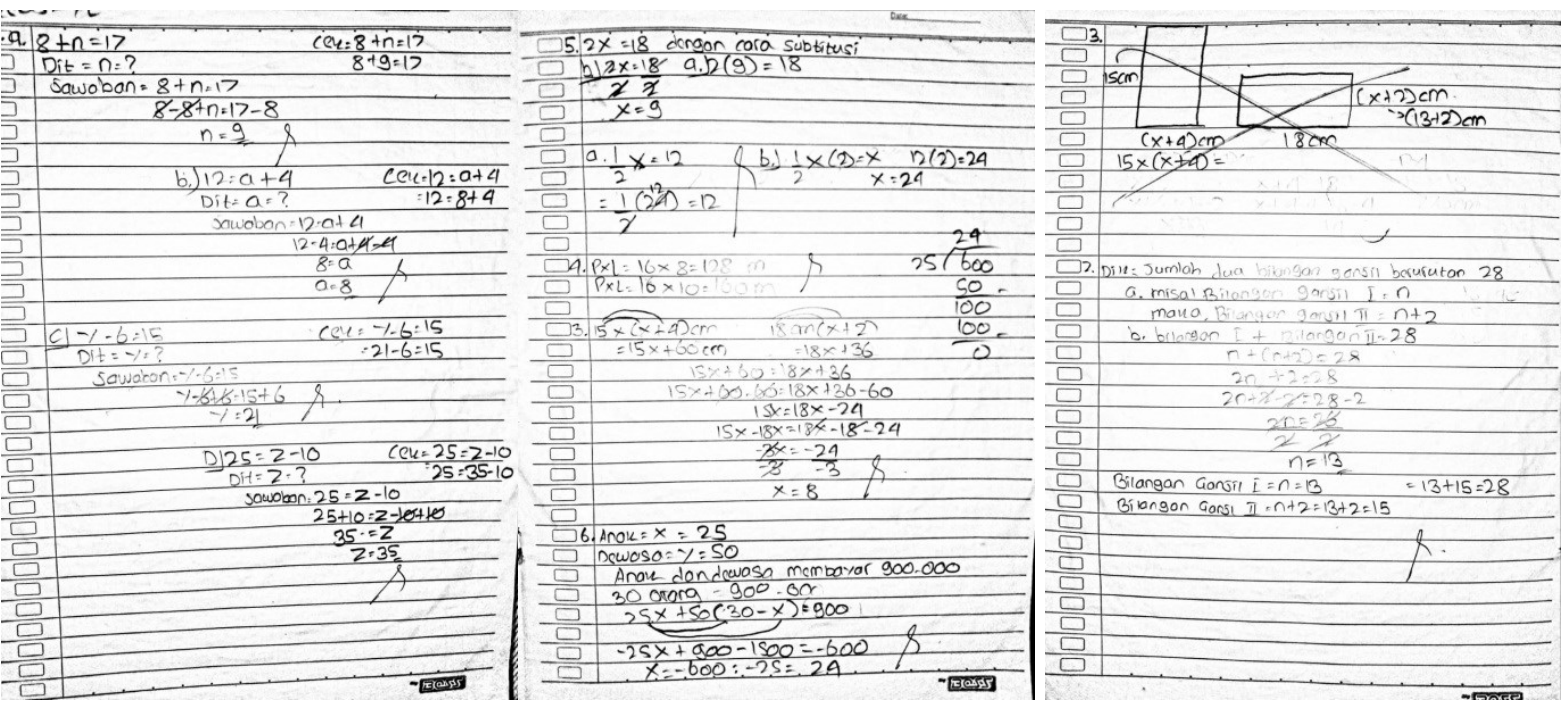

Gambar 1. Jawaban siswa dengan skor tinggi pada soal kemampuan pemahaman matematik 


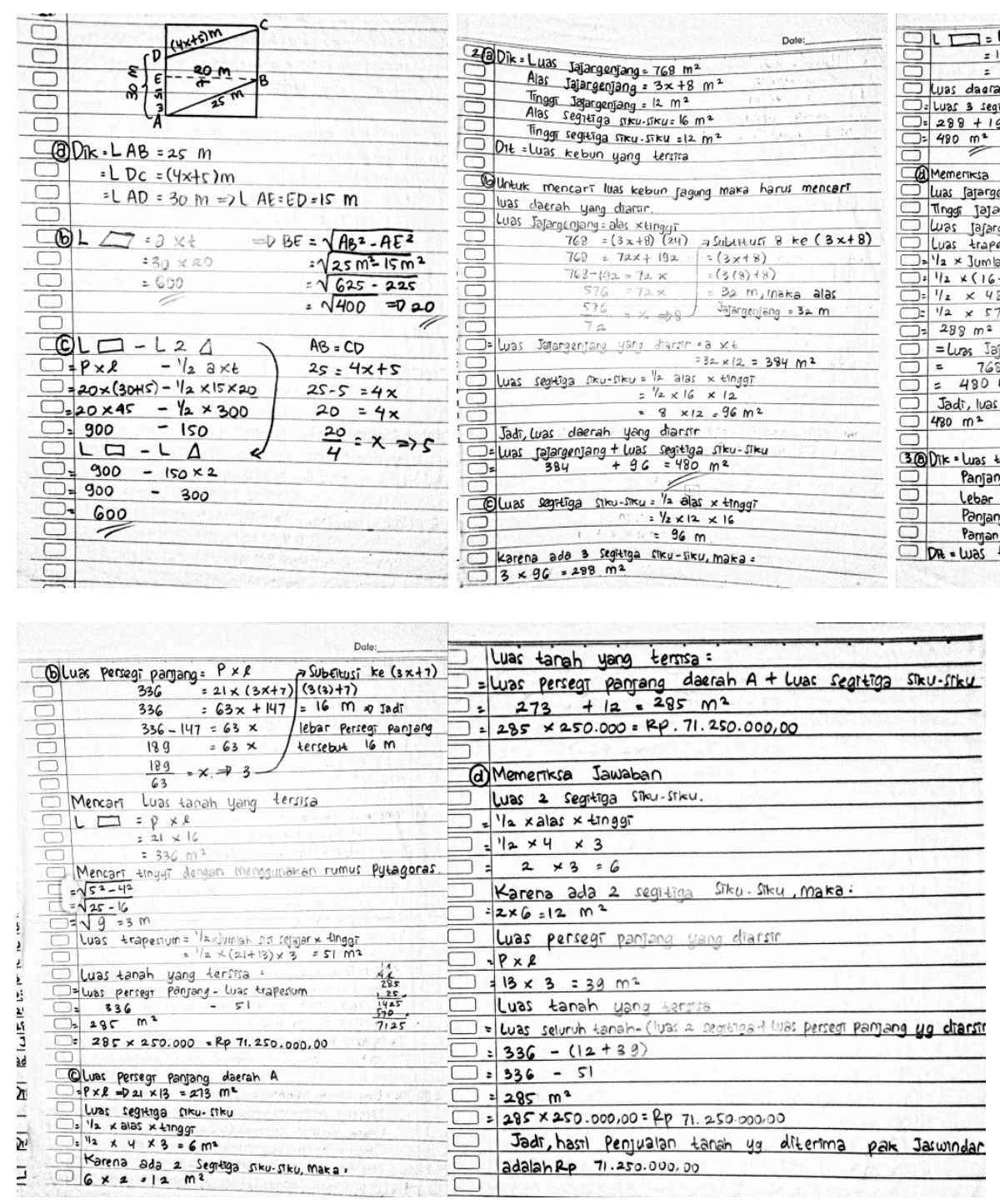

Gambar 2. Jawaban siswa dengan skor tinggi soal kemampuan pemecahan masalah matematik

Berdasarkan hasil tes tertulis diatas, pada soal kemampuan pemahaman matematik terlihat siswa dapat menggunakan rumus terkait perhitungan sederhana dan melakukan perhitungan algoritmik secara algoriotmik dengan tepat. Dengan demikian dapat dikatakan bahwa siswa tersebut dapat menyelesaikan soal pada indikator pemahaman komputasional. Dalam menggabungkan satu konsep dengan konsep yang lain dan mengetahui metode yang dikerjakan, menunjukkan bahwa siswa dapat melakukan hal tersebut dengan baik. Siswa dapat menyelesaikan soal secara tepat disertai dengan proses penyelesaian yang tepat dan teratur antara proses satu dengan lainnya.

Pada soal kemampuan pemecahan masalah matematik terlihat siswa dapat menyatakan apa yang diketahui, ditanyakan dan kecukupan data yang terdapat dalam soal secara tepat. Selain itu siswa dapat menyangkut-pautkan antara informasi yang ada pada soal, serta dapat menentukan langkah-langkah yang digunakan dalam menyelesaikan soal. Dalam hal ini siswa dapat melakukannya secara tepat namun masih ada sedikit jawaban yang perhitungannya 
Berdasarkan hasil tes tertulis diatas, siswa terlihat dapat menggunakan rumus terkait perhitungan sederhana dan melakukan perhitungan algoritmik secara algoriotmik namun siswa masih kurang dalam menerapkan rumus dengan tepat pada beberapa soal yang telah diberikan. Dengan demikian dapat dikatakan bahwa siswa tersebut mampu menyelesaikan soal pada indikator pemahaman komputasional dengan cukup baik. Dalam menggabungkan satu konsep dengan konsep yang lain dan mengetahui proses yang dikerjakan, menunjukkan bahwa siswa dapat melakukan hal tersebut dengan cukup baik, karena dalam pengerjaan konsep masih ada soal yang belum tepat.

Pada soal kemampuan pemecahan masalah matematik siswa terlihat kurang terampil dalam menyatakan apa yang diketahui, ditanyakan dan kecukupan data terkait soal yang telah diberikan secara tepat. Selain itu siswa kurang dapat menyangkut-pautkan antara informasi yang ada pada soal sehingga siswa kurang dapat menyelesaikan soal secara tepat karena masih ada jawaban yang perhitungannya kurang teliti. Sedangkan untuk tahap menguji kembali kebenaran jawaban yang sudah diperoleh terlihat siswa kurang dapat melakukannya, ia tidak bisa menemukan cara lain yang dapat dikaitkan dengan unsur yang telah diketahui pada soal.

Selanjutnya, berdasarkan hasil wawancara yang dilakukan dengan siswa 2, cara yang ia lakukan agar bisa menjawab sembilan soal yang diberikan dan menerapkan rumus yaitu dengan menentukan terlebih dahulu apa yang diketahui, ditanyakan kemudian baru ia menjawabnya. Walaupun ia bisa menjawab sembilan soal tetap saja ia mengalami cukup banyak kesulitan seperti dalam menerapkan rumus yang mungkin ia tidak paham dan menurutnya jawaban yang dianggap sulit yaitu soal kemampuan pemahaman nomor 4, 5 dan soal kemampuan pemecahan masalah matematik nomor 3, karena kata-katanya rumit dan yang ia lakukan untuk menjawab soal yang sulit tersebut yaitu dengan mengarang saja.

\section{Deskripsi Subjek Berkemampuan Matematika Rendah dalam Kemampuan Pemahaman dan Kemampuan Pemecahan Masalah Matematik}

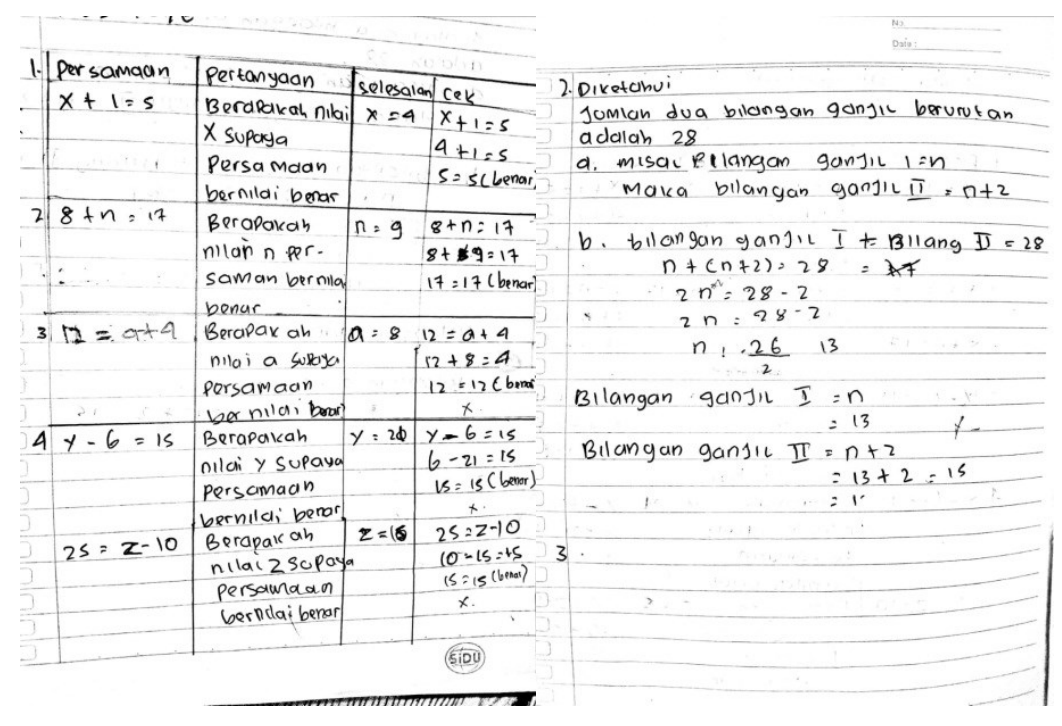

Gambar 5. Jawaban siswa dengan skor rendah pada soal kemampuan pemahaman matematik 


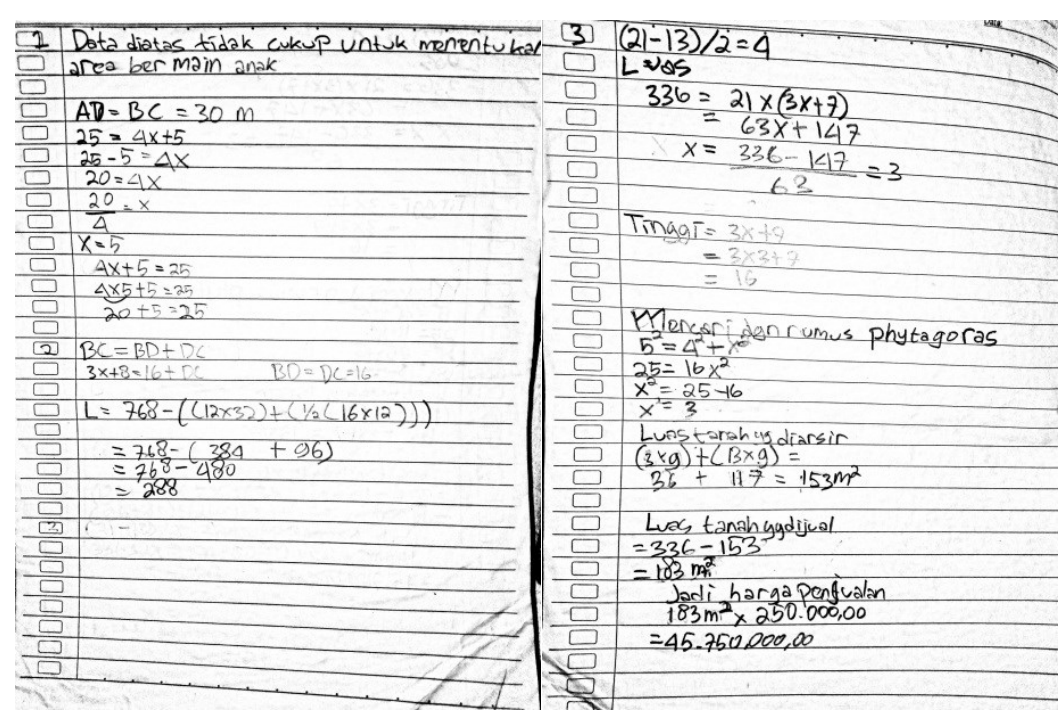

Gambar 6. Jawaban siswa skor rendah soal kemampuan pemecahan masalah matematik

Berdasarkan hasil tes tertulis diatas, dapat dilihat bahwa pada indikator pemahaman komputasional dan fungsional, siswa kurang dapat menggunakan rumus terkait perhitungan sederhana dan melakukan perhitungan algoritmik secara algoriotmik dengan tepat, selain itu siswa tidak dapat menggabungkan satu konsep dengan konsep yang lain dan mengetahui proses yang dikerjakan.

Pada soal kemampuan pemecahan masalah matematik siswa terlihat tidak terampil dalam menyatakan apa yang diketahui, ditanyakan dan kecukupan data terkait soal yang telah diberikan secara tepat. Selain itu siswa kurang dapat menyangkut-pautkan antara informasi yang terdapat pada soal sehingga siswa tidak dapat menjawab soal secara tepat. Sedangkan untuk tahap menguji kembali kebenaran jawaban yang sudah diperoleh, terlihat siswa tidak dapat melakukannya, ia tidak bisa menemukan cara lain yang dapat dikaitkan dengan unsur yang telah diketahui pada soal.

Selanjutnya, berdasarkan hasil wawancara yang dilakukan dengan siswa 3, cara yang ia lakukan agar bisa menjawab sembilan soal yang telah diberikan yaitu dengan mengarang saja. Ketika diberi pertanyaan mengenai kesulitan yang dihadapi saat menjawab sembilan soal tersebut ia merasa semua soal sulit. Ia pun tidak yakin dengan jawaban yang diberikan karena banyak soal yang tidak dijawabnya, dan soal yang dianggapnya sulit yaitu semuanya.

Hasil penelitian diatas, sejalan dengan hasil penelitian yang dilakukan oleh Martin, dkk (Martin, Tandililing, \& Yani, 2018) Berdasarkan hasil analisis tersebut ditemukan bahwa siswa yang mempunyai kemampuan pemahaman matematik yang rendah, sebagian besar $(80,9 \%)$ berasal dari siswa yang mempunyai kemampuan pemecahan masalah matematik yang rendah. Sedangkan kemampuan pemahaman matematik siswa yang baik, semuanya (100\%) berasal dari siswa yang kemampuan pemecahan masalah matematik yang baik. Kemudian, penelitian yang dilakukan Harry, dkk (Putra, Anggeraeni, Putri, Fitriana, \& Andayani, 2018) di SMP Mahardika menunjukkan bahwa kemampuan pemecahan masalah siswa di sekolah tersebut masih rendah terlihat dari hasil jawaban siswa saat diberikan soal, oleh karena itu siswa harus 
dilatih dan dibiasakan mengerjakan soal-soal pemecahan masalah, dengan dibiasakannya siswa untuk mengerjakan soal-soal tersebut maka siswa akan dengan mudah menjawab soal yang diberikan karena siswa sudah mengetahui tahap demi tahap yang harus dilakukan dalam menjawab soal sampai menemukan jawaban yang tepat, selain itu siswa pun akan terlatih untuk berpikir kreatif dan kritis karena siswa akan dituntut untuk bisa menemukan langkah atau cara yang digunakan untuk menjawab soal dengan pemikiran atau idenya sendiri.

\section{KESIMPULAN}

Berdasarkan hasil analisis kemampuan pemahaman dan kemampuan pemecahan masalah matematik siswa kelas VII-E SMPN 36 Bandung bila dilihat dari hasil jawaban dalam menyelesaikan soal persamaan linear satu variabel (PLSV) terdapat beberapa hal yang menyebabkan beberapa siswa masih salah dalam menjawab, hal tersebut dikarenakan beberapa siswa masih menganggap bahwa soal tipe kemampuan pemecahan masalah merupakan soal yang sulit dan dibutuhkan pemikiran yang kritis sehingga tidak adanya ketertarikan siswa untuk memahami soal yang diberikan, selain itu masih terdapat sejumlah siswa yang kurang teliti ketika menyelesaikan permasalahan dan kurang tepat dalam menentukan strategi penyelesaian hal tesebut berpengaruh terhadap jawaban akhir siswa. Dari data diatas terlihat bahwa setiap kesalahan dari indikator kedua kemampuan tersebut tergolong sangat rendah, hal ini membuktikan secara nyata adanya keterkaitan antara kemampuan pemahaman siswa dengan kemampuan pemecahan masalah matematik siswa sehingga dapat disimpulkan bahwa kedua kemampuan tersebut saling berhubungan.

\section{UCAPAN TERIMAKASIH}

Terimakasih kepada SMPN 36 Bandung yang sudah menerima dan memperbolehkan peneliti untuk mengadakan penelitian tentang Analisis Kemampuan Pemahaman dan Pemecahan Masalah Matematik Siswa SMPN 36 Bandung pada Materi Persamaan Linear Satu Variabel.

\section{DAFTAR PUSTAKA}

Aida, N., Kusaeri, K., \& Hamdani, S. (2017). Karakteristik Instrumen Penilaian Hasil Belajar Matematika Ranah Kognitif yang Dikembangkan Mengacu pada Model Pisa. Suska Journal of Mathematics Education, 3(2), 130. https://doi.org/10.24014/sjme.v3i2.3897

Fadhila, N., \& Sei, P. (2018). Analisis kemampuan pemecahan masalah matematika siswa smp it nurul fadhila percut sei tuan, (May).

Fauziah, A. (2005). Melalui Strategi React, (1994), 1-13.

Hendriana, H., \& Soemarmo, U. (2014). Penilaian Pembelaran Matematika. Bandung: PT. Reflika Aditama.

Hendriana, H., Rohaeti, E. E., \& Soemarmo, U. (2017). Hard Skills dan Soft Skills Matematika Siswa. Bandung: PT. Reflika Aditama.

Martin, Tandililing, E., \& Yani, A. (2018). Kemampuan Pemahaman dan Pemecahan Masalah Matematis Siswa SMP Melalui Model Pembelajaran Berbasis Masalah. Jurnal Pendidikan Dan Pembelajaran, 7(1), 1-19.

Muhsin, Johar, R., \& Nurlaelah, E. (2013). Peningkatan Kemampuan Pemahaman dan Pemecahan Masalah Matematis Melalui Pembelajaran dengan Pendekatan Kontekstual, 2, 13-24.

Putra, H. D., Anggeraeni, W., Putri, S., Fitriana, U., \& Andayani, F. (2018). Kemampuan Pemecahan Masalah Matematis dan Self-Confidence Siswa SMP. SJME (Suoremum Journal of Mathematics Education), 2(1), 60-70. 